\title{
Love in life and death
}

\author{
EIMEAR SPAIN*
}

\section{Centre for the Understanding of Emotions in Society, School of Law, University of Limerick}

T he issue of assisted dying is once again in the public consciousness given several recent high-profile cases challenging the legal prohibition on assisted dying in jurisdictions on both sides of the Atlantic. In June 2012, the Supreme Court of British Columbia declared the relevant provisions of the Canadian Criminal Code which prohibited assisted dying invalid on the grounds that they unjustifiably infringed the rights of the plaintiff under the Canadian Charter of Rights and Freedoms. ${ }^{1}$ Almost contemporaneously, the High Court of England and Wales heard a case in which it was argued that it would not be unlawful for a doctor to terminate the applicant's life or assist him in terminating his life on the basis of the defence of necessity. ${ }^{2}$ The applicant also asserted that art 8 of the European Convention on Human Rights (ECHR) is infringed by the current criminal law of England and Wales 'in so far as it criminalises voluntary active euthanasia and/or assisted suicide'. ${ }^{3}$ These cases raise many important issues for the criminal law, among them the role of the courts in deciding important moral and ethical debates, and the proper balance to be struck between the desire to protect the sanctity of life principle and the most vulnerable on the one hand, with the desire to respect individual autonomy and display compassion to individuals caught up in tragic circumstances on the other.

Central to any debate on this topic are the emotions which motivate those involved in assisted dying. It is difficult to imagine a more emotionally charged event than the taking of life, particularly the life of a loved one who is suffering, a fact often acknowledged by the courts. Yet, the courts, review bodies and commissions, legislators and commentators have yet to place emotions at the centre of the debate. This article will concentrate on the role which emotions play in end of life decisions, focusing on the proper legal response to such decisions given the strong emotions which underpin them. It seeks to address the questions of whether and why these emotions are relevant to the imposition of criminal liability by pointing to the properly exculpatory nature of emotions of this kind in the criminal law, particularly given the modern understanding of emotions as capable of both rationality and evaluation. In particular, we shall examine the existing state of the law in this area, focusing particularly on

* This paper was first delivered at an International Symposium on Emotion Regulation held in the University of Limerick in May 2012.

1 Carter v Canada (Attorney General) 2012 BCSC 886.

$2 \mathrm{R}$ (on the application of Tony Nicklinson) v Ministry of Justice [2012] EWHC 2381.

3 Ibid [5]. The High Court had previously stuck out the plaintiff's claim in relation to art 2 on the basis that he was not asserting a claim based on his asserted rights. 
the availability of existing criminal law defences and how these could be utilised, reformed or supplemented to deal with the circumstances under consideration. Following a review of the existing defences available to one who assists another to die, a new defence is proposed which looks to the love and/or compassion experienced by the defendant.

\section{The emotions of assisted dying}

That emotions are important to law, both in shaping the contents of the law and the behaviour of actors within the legal system is beyond doubt, and this special issue highlights the importance of emotions in a number of different contexts. ${ }^{4}$ The importance of emotions to the criminal law lies in their role in shaping human judgments and behaviours. If the criminal law is to punish individuals who commit criminal acts under the impulse of emotion, there should be some understanding and acknowledgment of the role which emotions play in motivating such actions and a consideration of their impact on the attribution of criminal responsibility. The emotions experienced by individuals who assist another to die are very often central to the decision to act, a reality recognised by the courts. Thus, for instance, in Inglis,, 5 the court acknowledged the emotions which motivated a mother who killed her severely disabled son by means of a heroin overdose, noting ' $[t]$ here was no malice, only love in [the] heart'. ${ }^{6}$

While love is the emotion most often associated with cases of assisted dying, this is not the only emotion engaged in these situations. Often actors will experience sadness at the plight of the sufferer and fear for the suffering and indignity they face. Compassion is also often mentioned in the context of assisted dying cases. However, while love is considered to be one of the basic or core emotions, ${ }^{7}$ there has been much controversy over the nature of compassion and whether it is properly categorised as an emotion at all. Three views have been put forward, one viewing compassion as a vicarious emotion, ${ }^{8}$ another seeing it as a variant of love or sadness ${ }^{9}$ and a third considering it as a distinct emotion in its own right. ${ }^{10}$ It is now increasingly recognised as a distinct emotion which 'arises in witnessing another's

4 See, generally, Terry Maroney, 'Law and Emotion: A Proposed Taxonomy of an Emerging Field' (2006) 30 Law Hum Behav 119 and Kathy Abrams and Hila Keren, 'Who's Afraid of Law and Emotion?' (2010) 94 Minn Law Rev 1997.

5 [2010] EWCA Crim 2637, [2011] 1 WLR 1110. The appeal against the appellant's conviction for murder and attempted murder was unsuccessful, but the nine-year minimum term of her mandatory life sentence was reduced to five years.

6 Ibid 1117. The court was in 'no doubt about the genuineness of her belief that her actions in preparing for and eventually killing Thomas represented an act of mercy or that the grief consequent on the loss of her son is undiminished by her responsibility for his death': ibid 1123.

7 Along with fear, anger, happiness, disgust, sadness and surprise. See Maroney (n 4).

8 In much the same way as empathy which is dependent upon one's apprehension of the emotions of others. For example, see Martin L Hoffman, 'Is Altruism Part of Human Nature?' (1981) 40 Journal of Personality and Social Psychology 121, 128; Susan Bandes, 'Empathetic Judging and the Rule of Law' (2009) Cardozo L Rev De Novo 133, 136-67.

9 For example, S Sprecher and B Fehr discuss compassionate love as 'an attitude toward other[s], either close others or strangers or all of humanity; containing feelings, cognitions, and behaviors that are focused on caring, concern, tenderness, and an orientation toward supporting, helping, and understanding the other[s], particularly when the other[s] is [are] perceived to be suffering or in need': 'Compassionate Love for Close Others and Humanity.' (2005) 22 Journal of Social and Personal Relationships 629, 630. See also B Fehr, S Sprecher and L G Underwood (eds), The Science of Compassionate Love: Theory, Research, and Applications (WileyBlackwell 2008) 81-120.

10 Richard S Lazarus, Emotion and Adaptation (OUP 1991) 289; Jennifer L Goetz, Dacher Keltner and Emiliana Simon-Thomas, 'Compassion: An Evolutionary Analysis and Empirical Review' (2010) 136(3) Psychological Bulletin 351, 351. 
suffering and that motivates a subsequent desire to help',11 clearly a factor of great importance in many cases of assisted dying. This article will focus on the emotions that are most central to the decision to assist another to die, namely love and compassion. However, we must always be cognisant of the fact that emotions such as these will not always be engaged in cases of assisted dying and any proposals for reform which place these emotions at their core must be able to deal with this concern. ${ }^{12}$

The first issue to be considered is just how emotions arise and influence the decisions we take, drawing on literature from other disciplines, particularly psychology. Law typically conceives of emotions as irrational forces which 'overcome' us, as embodied by the provocation defence. However, from a psychological perspective, emotions are now commonly understood to result from a cognitive, if not always conscious, appraisal of the personal relevance of a situation to the individual in line with their beliefs, goals, values and morals. Thus, Fridja notes that '[t]here seems little doubt that the meaning of events (their implications for well-being and the achievement of goals and values), rather than their objective nature as stimuli, is the primary determinant of most emotions'. ${ }^{13}$ Emotions provide vital information to both ourselves and to third parties about what is valued in life, that is, our goal hierarchies, and accordingly shape our behaviour. ${ }^{14}$ Glore suggests that '[e]motions not only serve an informational role, signalling the value of things, but it is also an embodiment of such value. Rather than simply believing something to be of value, emotion creates a direct experience of that value. ${ }^{15}$ Empirical research also supports the view that by focusing attention and increasing awareness, emotions assist us in processing events and situations on a deeper level than one would in their absence. ${ }^{16}$ In the words of de Sousa: 'when the calculi of reason have become sufficiently sophisticated, they would be powerless in their own terms, except for the contribution of emotion'. ${ }^{17}$

Emotions are also linked to rationality in that they follow a train of reasoning and embody our judgments about the situation and our own goals, values and morals rather than being merely forces which overwhelm us, and as such are capable of being judged. ${ }^{18}$ That is, they can be evaluated to consider if they were reasonable or normatively acceptable in a given situation. ${ }^{19}$ Emotions are therefore rational in a very important sense. However, it is

11 Goetz et al (n 10). Following an evolutionary analysis, Goetz et al suggest that 'compassion evolved as a distinct affective experience whose primary function is to facilitate cooperation and protection of the weak and those who suffer'. The authors conclude that compassion 'arises out of distinct appraisal processes and has distinct display behaviours, distinct experiences, and an approach-related physiological response’: 368.

12 It must also be considered that medical professionals and or others who do not have a close relationship with the individual sufferer will be more likely to feel compassion rather than love when observing an individual in pain and distress. Compassion and love are considered to be separate emotions which are not necessarily preceded or accompanied by one another: Goetz et al (n 10) 355.

13 N H Frijda, 'Emotions Require Cognition, Even If Simple Ones', in P Ekman and R J Davidson (eds), The Nature of Emotions: Fundamental Quest (OUP 1994) 197.

14 Robert de Sousa, The Rationality of Emotions (MIT Press 1987) 9; Gerald L Clore, 'Why Emotions are Felt', in Ekman and Davidson (n 13) 103-11; Lazarus (n 10) 22; N Eisenberg, 'Emotion, Regulation, and Moral Development' (2000) 51 Ann Rev Psych 665, 665.

15 Gerald L Clore, 'For Love or Money: Some Emotional Foundations of Rationality' (2005) 80 Chicago-Kent L Rev 1151, 1152.

16 See Jeremy Blumenthal, 'Does Mood Influence Moral Judgement?: An Empirical Test with Legal and Policy Implications' (2005) 29 L and Psychology Rev 1, generally and 18 specifically.

17 de Sousa (n 14) xv.

18 Or are at least capable of rationality; see Martha Nussbaum, Hiding from Humanity: Disgust, Shame and the Law (Princeton University Press 2004) 10.

19 Thus, de Sousa links emotions to rationality given 'judgements of reasonableness, the use of emotions as excuses and justifications, and the thought-dependency of most emotions': de Sousa (n 14) 5. 
important to realise that, while emotions are capable of rationality, they will not always be objectively rational. For example, they may result from a misinterpretation of the situation, an overestimation of the personal relevance of a situation or a flawed value system. ${ }^{20}$ Emotions can sometimes also be irrational in that they may 'rearrange the priorities of goals'. ${ }^{21}$ So, while ordinarily one's primary priority may be self-preservation, love may cause one to forgo this primary goal in favour of a loved one. ${ }^{22}$ In this way, emotions may cause an individual to act in a way which is not consistent with their settled values in the absence of emotion. So, for example, while ordinarily one may abhor violence, hold human life in the highest esteem and prefer to obey the law, when faced with a loved one facing a slow and agonising death, love and compassion may cause one to re-evaluate what is important in the circumstances and result in a decision to take a life. It is for this reason that emotions are often considered to be irrational. However, it must be remembered that these ongoing goals and values are reassessed in light of the particular circumstances, in this case seeing someone whom you love dying in a slow and painful way. It is also clear that emotions will not always cause one to take the course of action which is most advantageous for society as a whole; they are based on subjective assessments of the personal relevance of a situation to the individual involved, given their goal hierarchies and morals amongst others. ${ }^{23}$ This fact is of great significance when considering the legal response to actions taken while under the influence of emotion, particularly in deciding whether a defence of this nature should be based in justification or in excuse. ${ }^{24}$

Given the modern understanding of emotions as being capable of both rationality and, importantly for attributions of legal responsibility, capable of being judged as reasonable or unreasonable, it is argued that the law should recognise the exculpatory nature of certain emotions, in particular, the love and compassion which motivates individuals to assist their loved ones to die. Before exploring the question of how the law should respond, it is necessary to examine the current legal position for those who take a life in these circumstances.

\section{The current legal position}

This debate regarding the law in this area is often highly charged and confusing, not least because of the different contexts in which life is taken and the lack of consistency in the terminology used. 'Euthanasia' is considered to be the deliberate ending of another's life by a third party and may be voluntary or involuntary, such as when an individual is unable to express a desire to die. 'Assisted suicide' occurs where one takes one's own life with help from another, including information and medication. So death may take place with consent or in the absence of consent of the dying individual and may be effectuated by the individual themselves, a loved one, a medical professional, or a third party. The relationship between the individual whose life is ended and the actor is very important in this context as the emotions motivating the actor will vary accordingly. The term employed in the course of this discussion to cover all the situations outlined above is 'assisted dying. ${ }^{25}$

20 Nussbaum (n 18) 11-12.

21 Keith Oatley and Jennifer M Jenkins, 'Human Emotions: Functions and Dysfunction' (1992) 43 Ann Rev Psych 55, 60.

22 James R Averill, 'Emotions are Many Splendored Things', in Ekman and Davidson (n 13) 100.

23 Ibid 100.

24 See below at nn 128-32.

25 A term recently utilised by the British Columbia Supreme Court encompassing both assisted suicide, physician assisted suicide and voluntary euthanasia: Carter v Canada (Attorney General) 2012 BCSC 886 [39]. 
The legal ramifications for those who assist another to die vary across jurisdictions. Euthanasia and/or assisted suicide is permitted in various jurisdictions including Oregon, ${ }^{26}$ Washington, ${ }^{27}$ Switzerland, ${ }^{28}$ Belgium, ${ }^{29}$ Luxembourg ${ }^{30}$ and the Netherlands. ${ }^{31}$ However, the legal position in these jurisdictions is the exception rather than the rule. In the pages which follow we shall examine the legal position regarding assisted dying in the British Isles by looking first at the relevant crimes that may be committed and then at the possible defences that may be raised.

\section{CRIMES}

In the Republic of Ireland, those who assist another in dying without actually killing the person concerned may be charged with assisting suicide under the Criminal Law (Suicide) Act 1993 which makes it an offence to aid, abet, counsel or procure the suicide of another person, or an attempt by another person to commit suicide. This offence carries a maximum penalty of 14 years' imprisonment and the maximum sentence mirrors that in the Criminal Justice Act (Northern Ireland) $1966^{32}$ and the Suicide Act 1961, ${ }^{33}$ which operates in England and Wales. Similar legislation in England and Wales and in Northern Ireland makes it an offence to do 'an act capable of encouraging or assisting the suicide or attempted suicide of another person 34 with the intention to encourage or assist suicide or attempted suicide. 35

In both the UK and Ireland, those who actively take a life in these circumstances are liable to be convicted of murder and sentenced to life imprisonment. In the words of Lord Judge CJ, 'the law of murder does not distinguish between murder committed for malevolent reasons and murder motivated by familial love. Subject to well established partial defences, like provocation or diminished responsibility, mercy killing is murder. ${ }^{36}$ In this connection the law considers the life expectancy of the victim to be irrelevant, with the same penalty attaching to shortening a life by one hour as 50 years. ${ }^{37}$

26 Death with Dignity Act 1994. Physician assisted suicide is available exclusively for terminally ill patients under s 2.01 and euthanasia is specifically excluded.

27 Here assisted suicide was legalised in the Death with Dignity Act 2008.

28 Inciting or assisting suicide for selfish motives is prohibited under art 115 of the Swiss Penal Code. Therefore, anyone who assists a person to commit suicide for non-selfish reasons commits no crime. Euthanasia, on the other hand, is prohibited under art 114 which prohibits 'death on request'. However, this crime carries a lower minimum sentence than that of murder or manslaughter under Swiss law.

29 Both physician assisted euthanasia and physician assisted suicide are permissible subject to certain conditions under the 28 May 2002 Act on Euthanasia. While physician assisted euthanasia is explicitly legalised under certain conditions, physician assisted suicide is only implicitly included.

30 Physician assisted euthanasia and assisted suicide is permitted in this jurisdiction. A physician will not be prosecuted if certain conditions are satisfied under the Law of 16 March 2009 on Euthanasia and Assisted Suicide.

31 Termination of Life on Request and Assisted Suicide (Review Procedures) Act 2002 (Wettoetsing levensbeëndiging op verzoek en bulp bij zelfdoding (Euthanasiewet)). Both euthanasia and assisted suicide are prohibited under criminal law but an exception is created in the Act for physicians who act to assist another in committing suicide or actively take a life, subject to satisfying certain conditions, including that patients must be experiencing unbearable physical or mental suffering, with no prospect of relief. Other jurisdictions which permit assisted dying include Montana, which also recognises a defence of consent to homicide by a physician of a terminally ill patient, and Columbia, which permits physician assisted dying for terminally ill patients, see Sentencia C-239/97.

$32 \mathrm{~S} 13$.

$33 \mathrm{~S} 2$.

34 S 2(a) of the Suicide Act 1961; s 13(1)(a) of the Criminal Justice Act (Northern Ireland) 1966 (both as amended by the Coroners and Justice Act 2009).

35 S 2(b) of the Suicide Act 1961, s 13(1)(b) of the Criminal Justice Act (Northern Ireland) 1966 (both as amended by the Coroners and Justice Act 2009).

36 Inglis [2010] EWCA Crim 2637, [2011] 1 WLR 1110, 1118.

37 Ibid. 
However, in many cases a difficulty arises in determining the exact cause of death due to the weakened state of the victims and a charge of attempted murder rather than murder is sometimes levelled. ${ }^{38}$

This is not to say that the law does not recognise some circumstances where a course of action which will ultimately result in the death of an individual is legally permissible. First, individuals have the right to refuse medical treatment, even if this decision will result in their death. ${ }^{39}$ Secondly, the courts recognise the validity of the doctrine of 'double effect' that recognises that treatment provided to ease pain or for valid medical reason, which has the additional effect of ending the patient's life, is permissible. ${ }^{40}$ Thirdly, it is also permissible in certain circumstances to withdraw treatment from a patient even though this will inevitably result in death. ${ }^{41}$ Thus, in the Irish case of $\mathrm{Re}$ a Ward of Court, ${ }^{42}$ the applicant ${ }^{43}$ sought an order directing that all artificial nutrition and hydration of the patient should cease and for directions as to her future care. The patient was in a near persistent vegetative state (PVS) following complications which arose during a minor gynaecological operation under general anaesthetic more than 20 years before. ${ }^{44}$ The Supreme Court found that the withdrawal of feeding tubes was in the best interests of the ward and affirmed the High Court decision to consent to the withdrawal. A clear distinction was drawn between this and a positive action to take life. In this connection, Hamilton CJ noted that there was no 'right to have life terminated or death accelerated and [the right] is confined to the natural process of dying. No person has the right to terminate or to have terminated his or her life, or to accelerate or have accelerated his or her death.' 45

A similar distinction between the withdrawal of treatment or care and active euthanasia was made by the House of Lords in Airedale NHS Trust $v$ Bland. ${ }^{46}$ The patient in this case had been injured in the Hillsborough football stadium disaster and had been in a PVS for over three years with no hope of recovery. The applicants in this case sought a declaration from the court that it would be lawful to end medical treatment and discontinue ventilation, hydration and nutrition by artificial means, an application opposed by the Official Solicitor. ${ }^{47}$ The court found that it was permissible for doctors to withdraw feeding and hydration tubes ${ }^{48}$ even though this would inevitably result in the death of the patient from

38 As in Cox (1992) 12 BLMR 38 where the defendant was convicted of attempted murder rather than murder due to the difficulty in ascertaining the cause of death following an injection of drugs into a woman's heart aimed at ending her suffering.

39 See Re a Ward of Court (No 2) [1996] 2 IR 79; Re T [1992] 4 All ER 649; Re B [2002] 2 All ER 449. Generally, see Ciara Staunton, 'The Development of Health Care Planning in Ireland' 2009 15(2) MLJI 74-81.

40 See Airedale NHS Trust v Bland [1993] AC 789, 867 (Lord Goff); A, B and C v Ireland, Application No 25579/05 16 December 2010 (2011) 53 EHRR 13. For discussion in an Irish context, see Jennifer Schweppe, "Taking Responsibility for the "Abortion Issue": Thoughts on Legislative Reform in the Aftermath of $A, B$ and $C$ (2011) 14(2) IJFL 50; Deirdre Madden, Medicine, Ethics and Law (Butterworths 2002). This situation is distinguished from that where the doctor's purpose is to end life and has been criticised as a fiction: A C Grayling, Ideas that Matter (Weidenfeld \& Nicholson 2009) 134; Suzanne Ost, "Euthansia and the Defence of Necessity: Advocating a More Appropriate Legal Response' [2005] Criminal Law Review 355; compare J M Finnis, 'Bland: Crossing the Rubicon' (1993) 109 LQR 329.

41 In R (Burke) v GMC [2005] EWCA Civ 1003, it was held that it is not permissible to withdraw treatment from a competent patient against his/her wishes and that to do so would violate art 2 of the ECHR.

42 [1996] 2 IR 79.

43 The ward's mother was appointed as committee of the ward's person and estate.

44 By a majority of four to one, Egan J dissenting. For the full facts see [1996] 2 IR 79 at 85-88.

45 Ibid 124.

46 [1993] AC 789.

47 Ibid: see David Ormerod, Smith and Hogan's Criminal Law (13th edn, OUP 2011) 77-79.

48 Feeding and hydration were classified as medical treatment. 
dehydration and/or starvation, but that it would be impermissible for them to hasten the patient's death by a positive act, such as giving him or her a lethal injection. ${ }^{49}$ This decision has been the subject of much debate, particularly the rather artificial distinction drawn between active steps and omissions resulting in the death of the patient. ${ }^{50}$ The withdrawal of the feeding tube was considered to be a lawful omission, ignoring the fact that removing a piece of medical equipment that is already there, as opposed to failing to put something in place that was not, involves an element of positive conduct. Lord Goff acknowledged that such a stance:

may lead to a charge of hypocrisy; because it can be asked why, if the doctor, by discontinuing treatment, is entitled in consequence to let his patient die, it should not be lawful to put him out of his misery straight away, in a more humane manner, by lethal injection, rather than let him linger on in pain until he dies. ${ }^{51}$

While the above-mentioned cases relate to patients in a PVS, the decision facing the loved ones involved in cases of this nature reflects that faced by many competent individuals whose poor quality of life results in a wish to die. They face a choice between continuing to live in a state which is unacceptable to them, or starving to death. These concerns were raised in Inglis ${ }^{52}$ where the defendant was charged with murder and attempted murder having given a lethal injection of heroin to her son who had suffered catastrophic brain injuries in a fall. In this case 'the appellant explained that she had become increasingly concerned about the consequences of the possible withdrawal of hydration and nutrition in due course. She thought that this would be a dreadful death, dreadful for [her son] and this time, she wanted to do the job properly. ${ }^{53}$ Similarly, in the recent case of $R$ (on the application of Tony Nicklinson) $v$ Ministry of Justice, ${ }^{54}$ the applicant recognised that this option was available to him, but quite understandably indicated that he did not see this as a viable course of action. In this case the applicant suffered a severe stroke in 2005 which left him paralysed below the neck and unable to speak, dependent on carers and with very limited means of communicating with the outside world. Mr Nicklinson's case was particularly problematic given that his physical condition made it impossible for him to take positive steps himself to take his life; assisted suicide was not an option. ${ }^{55} \mathrm{He}$ was adamant that he did not wish to die of thirst. He unsuccessfully argued that 'the common law should develop or change to provide a lawful route to ending his suffering by ending his life at a time of his choosing with the assistance by positive action of a doctor in controlled circumstances that have been sanctioned by the court'. ${ }^{56}$ Despite her support for the decision to refuse his application for judicial review, Macur J noted:

49 Lord Goff noted that 'it is not lawful for a doctor to administer a drug to his patient to bring about his death, even though that course is prompted by a humanitarian desire to end his suffering, however great that suffering may be ... So to act is to cross the Rubicon which runs between on the one hand the care of the living patient and the other hand euthanasia - actively causing his death to avoid or to end his suffering. Euthanasia is not lawful at common law.' [1993] AC 789, 865.

50 See further Brian Hogan, 'Omissions and the Duty Myth' in Criminal Law: Essays in Honour of J C Smith (Butterworths 1987) 85 .

51 Ibid.

52 [2010] EWCA Crim 2637, [2011] WLR 1110.

53 Ibid 116.

54 [2012] EWHC 2381 (Admin).

55 Ibid [16]. The court accepted that he would be unable to commit suicide himself despite discussing the possibility of using a computer which would administer a fatal dose of drugs on Mr Nicklinson's command.

56 Nicklinson [2012] EWHC 2381 (Admin) [18]. 
the dire physical and emotional predicament facing Tony and Martin and their families may intensify any tribunal's unease identified by Lord Mustill in Bland ... in the distinction drawn between 'mercy killing' and the withdrawal of life sustaining treatment or necessities of life. ${ }^{57}$

\section{DEFENCES}

For those who find themselves subject to criminal charges in relation to a death through assisted dying, there are several existing criminal defences which are potentially available. In particular, attempts have been made in the past to excuse or partially excuse killing in these circumstances using the defences of diminished responsibility, provocation (or loss of selfcontrol) and necessity.

\section{Diminished responsibility}

In Ireland, the partial defence of diminished responsibility is available to those who kill another while suffering from a mental disorder that diminished substantially their responsibility for the act, despite not being enough to successfully raise an insanity defence. ${ }^{58}$ The formulation in England and Wales ${ }^{59}$ and in Northern Ireland ${ }^{60}$ allows a partial defence to defendants who kill another while suffering from an abnormality of mental functioning arising from a recognised medical condition ${ }^{61}$ that substantially impaired their ability to understand the nature of their conduct, to form a rational judgment or to exercise self-control and that provides an explanation for their acts and omissions in this regard. ${ }^{62}$ Given the differing formulations of the defence across the jurisdictions, caution must be exercised in drawing comparisons; however, the principal criticisms of the application of the diminished responsibility defence in this context apply generally. ${ }^{63}$

The defence has been utilised successfully in a number cases of assisted dying, ${ }^{64}$ most recently the English Court of Appeal case of $W_{e b b} b^{65}$ where the 73 -year-old appellant was convicted of manslaughter by reason of diminished responsibility in relation to the death of his mentally ill wife. Mrs Webb was convinced that she was suffering from a terminal illness and wished to die. Following an attempted overdose by the victim, Mr Webb smothered his wife with a plastic bag. The Court of Appeal took the view that the defendant's actions were similar to an assisted suicide. ${ }^{66}$ While the acceptance by the jury of the defence of diminished responsibility allowed the court to reflect compassion at sentencing, this approach is open to criticism as resulting in the medicalisation of those

57 Nicklinson [2012] EWHC 2381 (Admin) [152].

58 S 6 of the Criminal Law (Insanity) Act 2006.

59 S 2 of the Homicide Act 1957 as substituted by s 52 of the Coroners and Justice Act 2009.

60 S 5 of the Criminal Justice Act (Northern Ireland) 1966 as substituted by s 53 of the Coroners and Justice Act 2009 .

61 Homicide Act 1957, s 2(1)(a). In Northern Ireland the requirement is for a recognised mental condition: Criminal Justice (Northern Ireland) 1966, s 5(1)(a).

62 This means that the abnormality of mental functioning must be a cause or contributing factor of D's conduct: Homicide Act 1957, s 2(1B); Criminal Justice Act (Northern Ireland) Act 1966, s 5(1B).

63 Louise Kennefick, 'Diminished Responsibility in Ireland: Historical Reflections on the Doctrine and PresentDay Analysis of the Law' (2011) 62 NILQ 269.

64 For example, see Lawson, The Times, 9 June 2001, Crown Ct (Maidstone). See also Law Commission, Report on Partial Defences to Murder (Law Com No 290, 2004) Appendix B, 'The Diminished Responsibility Plea in Operation - An Empirical Study'.

65 [2011] EWCA Crim 152. On appeal, his two-year sentence was reduced to a 12-month sentence.

66 Ibid [21]. 
who commit a putatively criminal act out of love and compassion. ${ }^{67}$ It suggests that one who takes a life in these circumstances is suffering from a mental condition rather than responding in a rational way to an extremely emotive situation. Its utility is also quite limited, as a medical professional who acted similarly in these circumstances would be unlikely to be able to claim a defence of diminished responsibility and, indeed, would be loath to do so given the personal and professional ramifications of such a defence: ' $[\mathrm{t}] \mathrm{he}$ lack of a close familial relationship means that the patient's suffering is unlikely to have the kind of severe emotional and psychological impact that could satisfy the requirements of diminished responsibility'.68

\section{Provocation}

The second defence available to one charged with murder in this connection is that of provocation, a defence available to individuals who lose self-control as a result of something said or done, implicitly recognising the exculpatory nature of anger. The precise nature of this defence differs across jurisdictions. Ireland retains a common law defence of provocation which requires that the 'provocative conduct must be such as to: (1) Actually cause in the defendant, a sudden and temporary loss of self-control making him so subject to passion that he or she is not the master of his/her mind. (2) Make a reasonable person (ordinary person) do as the defendant did. ${ }^{69}$ Until recently, a similar defence was available in England and Wales and in Northern Ireland where an individual was provoked to such an extent by things said or done to suddenly and temporarily lose self-control and the provocation was enough to make a reasonable man do as he did. ${ }^{70}$ This defence was recently replaced in England and Wales and Northern Ireland with the defence of loss of self-control, which retains the requirement that a defendant loses self-control as a result of a 'qualifying trigger' and that a person of the defendant's age and sex and with 'a normal degree of self-tolerance and self restraint and in the circumstances of $\mathrm{D}$, might have reacted in the same or in a similar way to D'. ${ }^{71}$ The new defence of loss of self-control contains no requirement that the loss of self-control be sudden or temporary, however, the defendant cannot act in a considered desire for revenge. ${ }^{72}$

In Inglis, ${ }^{73}$ the defendant was charged with attempted murder and murder in relation to the death of her son by means of a heroin overdose and raised the defence of provocation. ${ }^{74}$ Mrs Inglis's son had suffered catastrophic brain injuries in a fall from an ambulance and it was claimed that the defendant acted out of love; '[a]ccording to her account, once they were alone she injected him with a fatal dose of heroin, telling him, everything is fine. I love you. ${ }^{75}$ The application of the provocation defence in a case of this nature raises many

67 See Law Commission (n 64) 88-9.

68 Ost (n 40) 361.

69 Irish Law Reform Commission, Report on Defences in Criminal Law (LRC Rep 95-2009, 2009) para 4.59. See also People (DPP) v MacEoin [1978] IR 27; People (DPP) v Kelly [2000] 2 IR 1.

70 Duffy [1949] 1 All ER, 93n, as modified by s 3 of the Homicide Act 1957 in England and by s 7 of the Criminal Justice (Northern Ireland) 1966 in Northern Ireland.

71 Coroners and Justice Act 2009, ss 54-56. The 'qualifying triggers' identified in s 55 are a fear of violence emanating from the victim and/or 'things done or said (or both) which (a) constitute circumstances of an extremely grave character, and (b) cause D to have a justifiable sense of being seriously wronged'.

72 Ibid s 54(4).

73 [2010] EWCA Crim 2637, [2011] 1 WLR 1110.

74 The offence occurred before the coming into force of the Coroners and Justice Act 2009. The appeal against conviction for murder was dismissed, but the nine-year minimum term of the mandatory life sentence was reduced to five years.

75 [2011] 1 WLR 1110, 1115. 
uncomfortable questions. It is very difficult for one who takes a life in the circumstances envisaged in this article to satisfy two main elements of the defence: a requirement of an adequate provocation and loss of self-control. Very often, the taking of life in compassion and love is a deliberate act taken after much soul-searching, so it will be very difficult to satisfy a requirement of a sudden and temporary loss of self-control: ${ }^{76}$ '[i]n reality, in a true case of mercy killing, provocation is unlikely to provide any defence. The more likely defence would be diminished responsibility. ${ }^{77}$ The trial judge in Inglis removed the defence of provocation from the jury due to the lack of evidence that the defendant had lost selfcontrol, and this was affirmed in the Court of Appeal. In the words of Lord Judge CJ:

all the evidence demonstrated that the appellant applied her mind to her objective, which was to kill her son, and that she did so with scrupulous and meticulous care, and that in doing so she fulfilled her long-standing objective ... However, in relation to her son and his injuries, she was resolved that she should relieve him of his suffering. When she did so, she knew exactly what she was doing, and why she was doing it, and how it was to be done, and how it was imperative that its success should be assured. Far from lacking or losing selfcontrol (an essential ingredient for the defence of provocation) the appellant was completely in control of herself. ${ }^{78}$

The requirement of provocative conduct, or a qualifying trigger under the new law operating in England, Wales and Northern Ireland, is also problematic in this context. The position in Ireland is similar to that which previously pertained in England and Wales and in Northern Ireland, in that the provocative conduct need not be unlawful ${ }^{79}$ but there is some doubt whether circumstances alone can amount to a provocation. ${ }^{80}$ In Doughty, ${ }^{81}$ it was held by the English Court of Appeal that the crying of a baby was an adequate source of provocation, on the grounds that the relevant legislation in force at the time required everything done or said to be taken into account. ${ }^{82}$ Commenting on the decision, the late Sir John Smith pointed out that this was not a case of provocation by mere circumstances; rather, there was a human being who was the source of the provocation and against whom the resulting anger was naturally directed. ${ }^{83}$ In a similar way, in cases of assisted dying, the provocation can sometimes be attributed to the words or actions of the individual who is assisted in dying; however, it is hardly a conceptually pleasing result. While it may be possible to satisfy the requirement of an adequate provocation, the utilisation of this defence may seem to imply some form of wrongdoing on behalf of the victim, ${ }^{84}$ which runs counter to the very nature of these actions. Similarly, the 'qualifying triggers' identified

76 Above, $\mathrm{n} 70$.

77 [2011] 1 WLR 1110, at 1120. The Law Commission also took the view that the defences available in mercy killing cases were limited, noting: 'Unless able to avail him or herself of either the partial defence of diminished responsibility or the partial defence of killing pursuant to a suicide pact, if the defendant intentionally kills the victim in the genuine belief that it is in the victim's best interest to die, the defendant is guilty of murder.: Report on Murder, Manslaughter and Infanticide (Law Com No 304, 2006) pt 7.4.

78 [2011] 1 WLR 1110, 1118.

79 Doughty [1986] Crim LR 625; People (DPP) v Kehoe [1992] ILRM 481.

80 This was certainly the position in England and Wales: see Acott [1977] 2 Cr App R 94. However, it has been suggested that People (DPP) v Kehoe [1992] ILRM 481 supports the proposition that circumstances may be sufficient in Ireland: Conor Hanly, An Introduction to Irish Criminal Law (2nd edn, Gill \& Macmillan 2006) 224; Liz Campbell, Shane Kilcommins and Catherine O’Sullivan, Criminal Law in Ireland: Cases and Commentary (Clarus Press 2010) 1053.

81 [1986] Crim LR 625.

82 S 3 of the Homicide Act 1957.

83 Doughty [1986] Crim LR 625, 626 (commentary by J C Smith).

84 Campbell et al (n 80) 1044. 
in s 55 of the Coroners and Justice Act 2009 for the new defence of loss of self-control do not fit well with the nature of the actions under consideration here. The triggers identified are much stricter than the test under the old law and require either a fear of violence emanating from the victim and/or 'things done or said (or both) which (a) constitute circumstances of an extremely grave character, and (b) cause $\mathrm{D}$ to have a justifiable sense of being seriously wronged'. It seems that an attempt to claim this defence in respect of an act of assisted dying will fall at the first hurdle because acts of God, ${ }^{85}$ including illness, will not constitute 'things done or said' under s 55 .

Apart from the practical difficulties identified above, it is also important to note that, for those who take a life as a result of love or compassion, it would be difficult to accept the suggestion that the law recognises a partial defence on the basis that they lost selfcontrol as a result of anger or fear or, indeed, that they acted as a result of a mental impairment. 86 The rationale of a defence is very important to those claiming the defence and, on the principle of fair and proper labelling, defendants who assist another to die out of love and compassion should have a defence available to them that adequately reflects their motives. ${ }^{87}$ It is clear that some defendants may refuse to raise the defences discussed above as they wish their actions to be understood and would not wish their actions in taking the life of a loved one in love and compassion to be tainted by being associated with anger or mental impairment. It must also be remembered that, while both diminished responsibility and provocation (or loss of self-control) are partial defences which have the effect of removing the mandatory life sentence and allowing a reduced sentence, the defendant is still subject to a conviction for manslaughter. ${ }^{88}$

\section{Necessity}

The recent Nicklinson ${ }^{89}$ case has placed a third defence, that of necessity, at the forefront of the debate on assisted dying. While a necessity defence would provide a full defence if raised successfully, two hurdles must be surmounted. First, for those charged with murder, the court must accept necessity as a defence to that crime, where it has been specifically excluded in the past ${ }^{90}$ and, secondly, the defendant must fulfil the elements of the defence as set out by Brooke LJ in the case of $\operatorname{Re} A$ (Children) (Conjoined Twins: Surgical Separation), namely that '(i) the act is needed to avoid inevitable and irreparable evil; (ii) no more should be done than is reasonably necessary for the purpose to be achieved; and (iii) the evil inflicted must not be disproportionate to the evil avoided'. ${ }^{11}$ The claimant in Nicklinson argued before the High Court of England and Wales that on the basis of necessity it would not be unlawful for a doctor to terminate his life or assist him in terminating his life. He contended that on 'a humane application of Sir James Stephen's test, which Brooke LJ followed, the defence of necessity should be potentially available to a doctor who agreed to

85 See Ormerod (n 47) 518.

86 Similar arguments are made in relation to the medicalisation of the actions of women who kill their abusive husbands and rely on the defence of diminished responsibility. See Law Commission (n 64) 88-89.

87 This refers to the idea that the nature and gravity of an offender's wrongdoing should be fairly reflected by the label of the offence with which he or she is charged: J Chalmers and F Leverick, 'Fair Labelling in Criminal Law' (2008) 71 MLR 217.

88 These defences are only available on murder charges. Those charged with attempted murder or assisted suicide will still be subject to conviction and punishment, subject to prosecutorial discretion, jury nullification and compassion at sentencing.

89 Nicklinson [2012] EWHC 2381 (Admin).

90 See United States $v$ Holmes 26 F Cas 360 (1842); R v Dudley and Stephens (1884)14 QBD 273.

91 [2001] Fam 147, 240. 
terminate Tony's life at Tony's request'. ${ }^{92}$ This was a novel approach in England and Wales, where a necessity defence had never before been claimed in the context of an end of life decision. In an earlier High Court hearing, Charles J had found that it was arguable that the common law defence of necessity might develop to encompass voluntary active euthanasia and assisted suicide. ${ }^{93}$ Charles $J$ therefore gave permission to seek a declaration by means of a judicial review that a necessity defence would be available to a doctor who terminated or assisted in the termination of his life if the following conditions were met:

(a) the Court has confirmed in advance that the defence of necessity will arise on the facts of the particular case; (b) the Court is satisfied that the person is suffering from a medical condition that causes unbearable suffering; there are no alternative means available by which his suffering may be relieved; and he has made a voluntary, clear, settled and informed decision to end his life; (c) the assistance is to be given by a medical doctor who is satisfied that his or her duty to respect autonomy and to ease the patient's suffering outweighs his or her duty to preserve life. ${ }^{94}$

In coming to the decision to grant permission to seek the declaration, the court was referred to the writings of Glanville Williams, who noted the absence of a decision on this question and suggested:

[i]t is by no means beyond the bounds of imagination that a bold and humane judge might direct the jury, if the question was presented, that voluntary euthanasia may in extreme circumstances be justified under the general doctrine of necessity ... it is possible to imagine the jury being directed that the sanctity of life may be submerged by the overwhelming necessity of relieving unbearable suffering in the last extremity, where the patient consents to what is done and where in any event no span of useful life is left to him. ${ }^{95}$

However, the claim was ultimately rejected by the High Court. The claimant had relied on the case of $\operatorname{Re} A$ (Children) (Conjoined Twins: Surgical Separation), ${ }^{96}$ which had seen the expansion of the scope of the necessity defence to cover a situation which involved the separation of conjoined twins in circumstances where the operation would inevitably result in the death of the weaker twin. ${ }^{97}$ However, the court in Nicklinson was not willing to consider expanding the scope of the defence of necessity to circumstances of this nature and did not apply the test to the case before them. ${ }^{98}$ The case of $\operatorname{Re} A$ was distinguished on the basis that it 'was a case of highly exceptional facts, where an immediate decision was required. Tony's condition is tragic but sadly not unfamiliar.'99

92 [2012] EWHC 2381 (Admin) [72].

93 [2012] EWHC 304 (QB) [37].

94 [2012] EWHC $304(\mathrm{QB})$ [6].

95 Glanville Williams, The Sanctity of Life and the Criminal Law (Knopf 1957), referred to at [2012] EWHC 304 (QB) [10].

96 [2001] Fam 147.

97 Brooke LJ explicitly based his decision on the defence of necessity. Ward LJ's reasoning was founded in a defence of quasi-self-defence which has been interpreted as implicitly recognising a defence of necessity in Nicklinson [2012] EWHC 2381 (Admin): 'He did not use the language of necessity, but his reasoning may be said to fall within the doctrine.' [64] Walker LJ decided the case based on 'all three strands of necessity, lack of intent and lack of causation' [65].

98 The inevitable and irreparable evil which the claimant argued could only be avoided by his death was the continuation of his unbearable suffering contrary to rights of self-determination, dignity and autonomy: [2012] EWHC 304 (QB) [11].

99 [2012] EWHC 2381 (Admin) [74]. 
While the High Court of England and Wales was unwilling to develop the common law defence of necessity to encompass cases of assisted dying, it is arguable nonetheless that there is scope for the defence to develop in much the same way as the defence was developed to cover the separation of conjoined twins in the case of $\operatorname{Re} A .{ }^{100}$ It was argued that the case of $\operatorname{Re} A$ 'shows that the court is able to fashion means of permitting doctors to act in a way which accords with the demands of humanity'. ${ }^{101}$ Indeed, the court recognised that all previous statements on the question of a defence of voluntary active euthanasia, although of high persuasive authority, were not binding on the court. ${ }^{102}$ The primary hurdle to the expansion of the defence to cover cases of this nature is the reluctance of the judiciary to interfere with the proper role of Parliament. In the words of Toulson LJ:

To do as Tony wants, the court would be making a major change in the law ...

These are not things which the court should do. It is not for the court to decide whether the law about assisted dying should be changed and, if so, what safeguards should be put in place. Under our system of government these are matters for Parliament to decide, representing society as a whole, after Parliamentary scrutiny, and not for the court on the facts of an individual case or cases. For those reasons I would refuse these applications for judicial review. ${ }^{103}$

However, the court did recognise its power to develop the common law if necessary to ensure that the court (a public body under the Human Rights Act 1998) was acting in a way which was compatible with the ECHR. ${ }^{104} \mathrm{Had}$ the courts identified a breach of art 8 of the ECHR due to the lack of defence of voluntary active euthanasia, they would have declared such a defence to be available at common law. ${ }^{105}$ While the European Court of Human Rights has held that art 8 encompasses a right for an individual to decide how and when to end his or her life, the High Court was satisfied that the ban on voluntary euthanasia was within the margin of appreciation afforded to states under the ECHR. ${ }^{106}$ The court therefore rejected the applicant's arguments that art 8 required a defence of voluntary euthanasia to be made available, ${ }^{107}$ noting that the Suicide Act 1961 had previously been found to be compatible with art 8.108 Unfortunately for those seeking clarity in this confused area of law, although not for Mr Nicklinson, he died of natural causes before an appeal to the decision of the High Court could be heard so it is unlikely that a definitive Court of Appeal or Supreme Court ruling will be delivered in this case. ${ }^{109}$

Of course, this is not the first time the defence of necessity has been utilised in this context. In the Netherlands in the 1980s and 1990s, the courts recognised the availability of a defence of necessity in certain circumstances to doctors who administered voluntary

\footnotetext{
100 [2001] Fam 147.

101 [2012] EWHC 2381 (Admin) [63].

102 Ibid [51].

103 Ibid [150]; see also [151] (Royce J); and [152] (Macur J).

104 Ibid [18].

105 Ibid [19].

106 Ibid [121], citing Haas v Switzerland (2011) 53 EHRR 33; Pretty v UK (2002) 35 EHRR 1; and R (Purdy) v DPP [2009] UKHL 45, [2010] 1 AC 345.

107 [2012] EWHC 2381 (Admin) [122].

108 Ibid [148]; Pretty v UK (2002) 35 EHRR 1

109 In $R$ (on the application of Tony Nicklinson) v Ministry of Justice, DPP, High Court, 2 October 2012, the court refused permission to appeal or allow Mrs Nicklinson to be made a party to the proceedings as the court did not consider that the proposed appeal had any real prospect of success as any change to the law in this area was a matter for Parliament [9].
} 
active euthanasia to relieve suffering, ${ }^{110}$ and was followed by legislation legalising euthanasia in that jurisdiction. ${ }^{111}$ The defence of necessity has also been considered in this context by the Canadian Supreme Court in Latimer. ${ }^{112}$ Mr Latimer was convicted of killing his daughter by carbon monoxide poisoning. The victim suffered from a severe form of cerebral palsy, was in considerable pain and due to undergo a serious operation which would have resulted in considerable discomfort and involve an extended recovery period. The Supreme Court held that a necessity defence was unavailable to Mr Latimer on the facts as he failed to satisfy the criteria of the defence; not being in imminent danger, having reasonable legal alternatives available to him and taking actions which were disproportionate to the harm to be avoided. However, the court left 'open, if and until it arises, the question of whether the proportionality requirement could be met for a homicide'. ${ }^{113}$ It went on: '[a]ssuming for the sake of analysis only that necessity could provide a defence to homicide, there would have to be a harm that was seriously comparable in gravity to death (the harm inflicted). In this case, there was no risk of such harm.'114 Interpreting this authority in Carter $v$ Canada (Attorney General) ${ }^{115}$ recently, the court found that the defence of necessity 'is likely not available'. ${ }^{116}$

While the rationale of the defence of necessity may be considered to accord with the actions of those who assist individuals who are suffering to die, affording a defence to defendants who find themselves in difficult circumstances and as a result are forced to break the letter of the law, its basis in justification is problematic in the present context. Excusatory defences such as provocation and diminished responsibility recognise that the actor should not be held responsible or fully responsible, ${ }^{117}$ while condemning the act itself. Defences based on justification, such as necessity, on the other hand, exculpate a defendant on the basis that the act in which he or she engaged was justified and is not worthy of condemnation. ${ }^{118}$ The important communicative role of the law must not be ignored in this context. ${ }^{119}$ Seeking to justify the taking of life out of love and compassion is difficult given the competing moral stances. Accordingly, it may be assumed that it would be easier to excuse than to justify the taking of life in cases of assisted dying. Dressler argues that, rather than punish an individual because the act of killing is wrong, excuse requires us to exonerate because punishment is not 'necessarily, unalterably, and unfailingly'120 deserved, which seems to more adequately reflect the situation in assisted dying cases.

110 Schoonheim, Supreme Court, 27 November 1984, NJ 1985, No 106. The Postma decision (District Court, Leeuwarden, 21 February 1973, NJ 1973, No 183) was the first in the series and saw a physician who euthanised her 78-year-old mother sentenced to one week of probation for the crime of 'death on request', which was subject to a maximum sentence of 12 years. For discussion of these cases, see Carter $v$ Canada (Attorney General) 2012 BCSC 886 [457]-[9].

111 Above, n 31.

112 [2001] 3 LRC 593.

113 R v Latimer [2001] 3 LRC 593, 607.

114 Ibid.

1152012 BCSC 886.

116 Ibid [203].

117 There are differing theories of excuse including those based on 'choice', 'capacity' and 'character'.

118 Necessity is viewed as an excusatory defence in Canada. The Irish Law Commission also classified necessity as excusatory, without explaining the basis of this classification.

119 '[T] he criminal law fulfils an educational role that is also expressed in the distinctions that it makes among different kinds of acquittal.': Khalid Ghanayim, 'Excused Necessity in Western Legal Philosophy' (2006) XIX(1) CJLJ 31, 35.

120 Joshua Dressler, 'Exegesis of the Law of Duress: Justifying the Excuse and Searching for its Proper Limits' in Michael Louis Corrado (ed), Justification and Excuse in the Criminal Law: A Collection of Essays (Garland 1994) 406. 


\section{PROSECUTORIAL DISCRETION}

Individuals may also escape conviction in connection with the death of an individual through euthanasia or assisted suicide through the exercise of prosecutorial discretion. Prosecutions in Ireland in connection with the death of an individual through assisted suicide or euthanasia are rare. ${ }^{121}$ The Director of Public Prosecutions looks at each case 'on an individual basis and decisions are taken in accordance with the criteria set out in ... published guidelines for prosecutors' 122 rather than by reference to a specific set of guidelines in relation to assisted dying. The situation in England and Wales was formalised following the Debbie Purdy case ${ }^{123}$ with a set of guidelines for prosecutors issued in February 2010. ${ }^{124}$ These guidelines require prosecutors to apply the usual two-stage test in cases of assisted suicide: the first being the 'evidential' stage (asking whether there is a reasonable prospect of conviction); and the second the 'public interest' stage (asking whether prosecution would be in the public interest. ${ }^{125}$ In cases of assisted suicide, the first of these tests involves asking whether 'the suspect did an act capable of encouraging or assisting the suicide or attempted suicide of another person'; and whether 'the suspect's act was intended to encourage or assist suicide or an attempt at suicide'. ${ }^{26}$ As far as the public interest test is concerned, a prosecution will be less likely if:

1 the victim had reached a voluntary, clear, settled and informed decision to commit suicide;

2 the suspect was wholly motivated by compassion;

3 the actions of the suspect, although sufficient to come within the definition of the offence, were of only minor encouragement or assistance;

4 the suspect had sought to dissuade the victim from taking the course of action which resulted in his or her suicide;

5 the actions of the suspect may be characterised as reluctant encouragement or assistance in the face of a determined wish on the part of the victim to commit suicide;

6 the suspect reported the victim's suicide to the police and fully assisted them in their enquiries into the circumstances of the suicide or the attempt and his or her part in providing encouragement or assistance. ${ }^{127}$

121 A 45-year-old man (Gareth Volrath) was recently charged with murder in connection with the death of his 83year-old mother in a nursing home in County Waterford on 9 January 2012: Barry Roche, 'Man on Charge of Murdering his Mother in Care Home' The Irish Times (Dublin, 6 June 2012).

122 James Fogarty, 'Exit International Ireland Reports Growing Interest in Assisted Suicide' Medical Independent (Dublin, 17 May 2012) <www.medicalindependent.ie/page.aspx?title=exit_international_ireland_reports_ growing_interest_in_assisted_suicide $>$ accessed 2 August 2012.

$123 \mathrm{R}$ (on the application of Purdy) $v$ Director of Public Prosecutions [2009] UKHL 45.

124 Director of Public Prosecutions, Policy for Prosecutors in Respect of Cases of Encouraging or Assisting Suicide (February 2010). Similar guidelines were published in Northern Ireland by the Public Prosecution Service for Northern Ireland, Policy on Prosecuting the Offence of Assisted Suicide.

125 Code for Crown Prosecutors (2010), para 4.1.

126 Director of Public Prosecutions (n 124) para 17.

127 Ibid para 45. 
While this policy did not result in the decriminalisation of assisted suicide, there has been a significant decrease in the number of prosecutions in respect of assisted suicide since the policy was issued. 128

\section{Where to from here?}

Given the preceding discussion, which has highlighted the central role which emotions play in motivating behaviour and the important communicative effect of the law, it is of great concern that existing defences ignore or sideline the central role that emotions play in the decision of those who take the life of an individual who is suffering. While the defence of provocation implicitly recognises the role that emotion plays, the defence is focused on anger, an emotion which is not often associated with euthanasia or assisted suicide. ${ }^{129}$ Not only is this approach unsatisfactory in failing to adequately reflect the operating reasons of the individual who assists a loved one to die, it also privileges an emotion which is not generally considered to be socially desirable. ${ }^{130}$ There are some emotions, such as love and compassion, which may be classified as positive, as they are considered to 'have a proper role in human life'. ${ }^{131}$ These are the emotions which we as a society want to nurture and encourage, and our society is better for these emotions. Conversely, anger is not an emotion which is typically viewed as positive. ${ }^{132}$ While it is certainly arguable that there is a role for virtuous or righteous anger in any society, it is generally not an emotion we wish to cultivate. We do not encourage it in our children; instead, we teach them to respond calmly to frustrating situations and to manage their anger. The incoherency of privileging anger over other emotions has been recognised in many quarters. In its Report on Murder, Manslaughter and Infanticide, the Law Commission noted:

Under the current law, the compassionate motives of the mercy killer are in themselves never capable of providing a basis for a partial excuse. Some would say that this is unfortunate. On this view, the law affords more recognition to other less, or at least no more, understandable emotions such as anger (provocation) and fear (self defence). ${ }^{133}$

If the law recognises the exculpatory nature of an emotion such as anger, it is certainly arguable that one should be excused when one acts due to love or compassion. This argument is given credence by the modern understanding of emotions as reflecting both moral and rational decisions. ${ }^{134}$ Of course, as stated previously, not all decisions taken while under the influence of emotion will be rational or morally acceptable. However, if the emotions associated with cases of assisted dying, love and compassion are reasonable and socially acceptable, indeed desirable, and the response of the individual is reasonable and socially acceptable, then should the individual concerned be subject to punishment? This

128 Robert Winnett and Martin Beckford, '44 Cases of Assisted Suicide since CPS Guidelines Published' The Telegraph (London, 3 September 2011). Despite a total of 44 files being passed to the Crown Prosecution Service (CPS) since 2009, no prosecutions were brought for assisted suicide in England and Wales between February 2010 and September 2011. The High Court found in Nicklinson [2012] EWHC 2381 [123]-[44] that there was no legal obligation on the DPP to provide further clarity on this policy.

129 More recently, the role of fear in criminal defences has been recognised. For example, the defence of loss of self control recently introduced in England and Wales and Northern Ireland recognises a fear of violence emanating from the victim as a 'qualifying trigger': Coroners and Justice Act 2009, s 55.

130 See Robert C Solomon and Lori D Stone, 'On “Positive” and “Negative” Emotions' (2002) 32 (4) Journal for the Theory of Social Behaviour 417-35. See also Maroney (n 4) 134.

131 Anthony Duff, 'The Virtues and Vices of Virtue Jurisprudence' in T D J Chappell (ed), Values and Virtues (OUP 2006) 99.

132 Solomon and Stone (n 130).

133 Law Commission ( $\mathrm{n} 77$ ) pt 7.

134 Above, nn 14-25. 
gives rise to the following issues: (1) whether individuals who act in these circumstances should be partially or fully exculpated; (2) whether any new defence should be excusatory or justificatory in nature; (3) what the rationale of such a defence should be; and (4) the communicative effect of such a rationale.

\section{A new defence of assisted dying}

Given the criticisms outlined, it is suggested that it would be preferable to recognise a new defence available in cases of assisted dying rather than allowing the development of the law in this area by analogy, dependent on a case arising with an appropriate factual background, a sympathetic defendant, a receptive court and the whims of defence lawyers deciding on the appropriate defence to raise. Rather, it is suggested that an excusatory defence of assisted dying should be recognised, which is available to those who kill a suffering individual as a result of love and/or compassion. Individuals who act in these circumstances do not display evidence of a bad character deserving of punishment; his or her actions do not 'reflect on him [or her] in a way that makes the kind of criticism communicated by the imposition of criminal responsibility appropriate'. 135 Duff has suggested that people who act in these circumstances:

... should regret committing their crimes: indeed, they should repent them as wrongs. But the crimes were motivated by worthy emotions and virtuous commitments, and to resist the temptation to commit those crimes in those contexts would have required a moral strength whose lack we cannot justly condemn. ${ }^{136}$

In the same way, Dressler expresses the view of excuses as operating not just as an expression of compassion for the defendant but as operating when justice demands it; '[u]ltimately, excusing is a matter of justice, not of compassion'.137

While the rationality of emotions has been recognised, emotions will not always be rational in the sense that deliberate reflective judgments are rational, nor will the actions which result from them. ${ }^{138}$ There is therefore a clear risk that a defence of this nature would be open to abuse by unscrupulous members of society. In the words of the Law Commission:

there would need to be a much wider debate before concluding that the concept of compassion, as a motive, is in itself a sufficiently secure foundation for a mercy killing offence or partial defence... It is too important and socially significant a subject for us to make a recommendation without explicitly consulting on the question ... Others would say that recognising a partial excuse of acting out of compassion would be dangerous. Just as a defence of necessity can very easily become simply a mask for anarchy, so the concept of compassion vague in itself could very easily become a cover for selfish or ignoble reasons for killing, not least because people often act out of mixed motives. ${ }^{139}$

It is therefore important that, if a defence is to be recognised, the rationale for which is the love and compassion which the defendant was experiencing at the time he or she committed the putatively criminal act, that it be subject to an objective limitation, thereby ensuring the

135 Victor Tadros, Criminal Responsibility (OUP 2005) 49. See also William Wilson, 'The Filtering Role of Crisis in the Constitution of Criminal Excuses' (2004) 17 Can J L and Jurisprudence 387; John Gardner, 'The Gist of Excuses' (1997-1998) 1(2) Buff Crim L Rev 575.

136 Duff (n 131) 99-100.

137 Dressler (n 120) 398.

138 Samuel Pillsbury, 'Moralizing the Passions of Criminal Punishment' (1989) 74 Cornell L Rev 655, 679.

139 Law Commission (n 77) paras 7.29-30. 
normative acceptability of the defendant's actions in taking a life. As discussed previously, under the evaluative view of emotion, emotions are generated as a result of a cognitive appraisal of the personal relevance of a situation to an individual in line with one's values, goals, morals and capabilities and can be subject to judgment on the appropriateness of such emotions and the actions which result. ${ }^{140}$ The defence would essentially require that the emotion and subsequent response was reasonable and socially acceptable. ${ }^{141}$ This would require a consideration of whether a reasonable person sharing the characteristics of the accused would have experienced love or compassion ${ }^{142}$ in the circumstances and would have responded in a similar manner. Given the very real concerns surrounding grounding a defence in an emotion experienced by a defendant, it is suggested that this test of reasonableness should be supplemented by a requirement that the individual who was assisted in dying was suffering from a terminal or chronic illness or was suffering severely. That is, the condition must be objectively verifiable.

The defence would be available to individuals charged with a range of offences in connection with assisted dying, including murder, attempted murder or assisting suicide in the following circumstances:

1 an individual (D) assisted another to die as a result of love and/or compassion;

2 the emotion and subsequent response was reasonable;

3 the individual who was assisted in dying was suffering from a terminal or chronic illness or was suffering severely;

4 The individual had made a voluntary, clear, settled and informed decision to end his or her life. ${ }^{143}$

Given the nature of the emotions concerned, this defence would most often be claimed by those in a close relationship with the individual who is assisted to die. However, medical practitioners and third parties who assist in taking the life of an individual with whom they do not have such a relationship would be allowed to raise the defence provided that they acted purely out of compassion for the individual concerned. ${ }^{144}$ The approach recommended here does not legalise the offence, rather it recognises that, in some dire situations, in the face of extreme suffering, individuals, (including medical practitioners) may experience emotions 'whose primary function is to facilitate cooperation and protection of the weak and those who suffer'145 and the law cannot justly condemn those who act upon such emotions and assist another to end their suffering. ${ }^{146}$

140 Above, nn 19-20.

141 For further discussion of how an emotion-based defence would operate, including the objective test, see Eimear Spain, The Role of Emotions in Criminal Law Defences: Duress, Necessity and Lesser Evils (CUP 2011).

142 These concepts would not need to be defined in the legislation. Courts would follow the literal approach and give words their ordinary and everyday meaning, as in any other piece of legislation: Brutus v Cozens [1973] AC 854.

143 This would mean that the defence would not cover the taking of active steps to end the life of individuals who cannot communicate such a desire. However, it is argued that this condition is necessary to ensure that only individuals who have made a considered decision to die are covered.

144 Of course, many doctors would find it very troubling to be asked by a patient to assist in ending their life and the British Medical Association decided in June 2012 to maintain its opposition to the legalisation of assisted dying: <http://bma.org.uk/news-views-analysis/news/2012/june/bma-sticks-with-opposition-to-legalisingassisted-dying $>$ accessed 26 July 2012.

145 Goetz et al (n 10) 351.

146 Ibid. 


\section{Conclusion}

While the approach adopted here has been to focus on the recognition of a defence which operates to excuse individuals who have been charged with assisting another to die, this approach is certainly not without its drawbacks. Otherwise perfectly law-abiding citizens and their families, including often the individual who is assisted to die, will still face an enormously difficult situation, often without outside support. Those who rely on a defence of this nature are still subject to prosecution, with all the attendant distress, and doctors who assist patients to die face prosecution and censure. However, this approach serves to reflect the real value placed on human life in our society while achieving justice by excusing those who act in dire circumstances to relieve the suffering of another human being. Ultimately, a defendant who acts in an understandable way in response to reasonable and socially acceptable emotions should be exculpated. 
